\title{
Pengaruh Komposisi Media Tanam terhadap Pertumbuhan Taka Asal Kepulauan Seribu Sebagai Bahan Pangan Alternatif
}

\section{Effect Growing Media Composition on The Growth of Arrowroot from Kepulauan Seribu as an Alternative Food Resources}

\author{
Yenisbar*, Luluk P. Ekowahyuni, Umbu Yogi Pratama \\ Departement of Agrotechnology, Faculty of Agriculture, Universitas Nasional, Jakarta, Indonesia \\ ${ }^{*}$ Corresponding author. yenisbar.chaniago@gmail.com
}

Received: November 27, 2019; Accepted: March 18, 2020; Published: April 1, 2020

\begin{abstract}
Polynesia arrowroot as alternative food resource are rather difficult to be cultivated because of it's dormant tubers. The propagation needed techniques for growth media optimization to provide a source of planting material. This study aimed to determine the best black Polynesia arrowroot growth from Kepulauan Seribu from several combinations of planting media. The method used was Block Randomized Design (BRD) with planting media treatment $(\mathrm{M}): \mathrm{M} 1=$ large granule sand +soil+choarcoal $(1: 1: 1 \mathrm{v} / \mathrm{v}), \mathrm{M} 2=$ large granule sand+soil+organic fertilizer $(1: 1: 1 \mathrm{v} / \mathrm{v})$ and $M 3=$ large granule sand +soil+ organic fertilizer $(2: 1: 1 \mathrm{v} / \mathrm{v})$. Data were tested by IBM SPSS software version 23 and further tests using DMRT at a level of $5 \%$. The results showed the number leaves increase and plant height increase The best media treatment for number of leaves was large granule sand + soil, while the highest plant height in large granule sand + soil media + manure.
\end{abstract}

Key words: green house, organic fertilizer, tuber

Cite this as: Yenisbar, Ekowahyuni, L. P., \& Pratama, U. Y. (2020). Pengaruh Komposisi Media Tanam terhadap Pertumbuhan Taka Asal Kepulauan Seribu Sebagai Bahan Pangan Alternatif. Agrosains : Jurnal Penelitian Agronomi 22(1): 52-58. DOI: http://dx.doi.org/10.20961/agsjpa.v22i1.36012

\section{PENDAHULUAN}

Tumbuhan taka (T. leontopetaloides (L.) Kuntze) merupakan spesies herba berumbi yang termasuk ke dalam famili Taccaceae (Heyne, 1987). Taka dikenal dengan nama kecubung (Kepulauan Seribu), kecondang (Jawa), taka laut (Sumatera), totoan (Madura), jallawure (Garut), gadung tikus (Indonesia) arrowroot (Eng), lukeh (Malaysia), thaoyaimom (Thailand) (Santoso, 2014).

Hasil eksplorasi taka Ekowahyuni dan Yenisbar (2018) di Kepulauan Seribu, diantarannya Pulau Pramuka, Kotok Besar dan Karya terdapat 2 jenis warna tangkai daunnya yaitu warna hijau dan ungu kehitaman. Masyarakat di Kepulauan Seribu memanfaatkan umbi anak taka sebagai pangan dikarenakan tidak mengandung rasa pahit.

Tanaman taka merupakan salah satu tanaman yang banyak hidup di daerah pesisir. Taka termasuk tanaman herba perennial tumbuh tegak dan mempunyai daun yang berjumlah 1-3, dengan diameter berkisar antara $30-90 \mathrm{~cm}$. Daun berbentuk oval atau lonjong dengan ujung daun runcing (Meena dan Yadav, 2010). Tumbuhan ini memiliki batang semu tersembunyi di bawah tanah dan tertutupi oleh tangkai daun yang berbentuk bulat dan berongga (Gambar 1).

Umbi taka tumbuh di ujung akar yang mirip dengan kentang putih yang tumbuh $10-15 \mathrm{~cm}$ di bawah permukaan tanah, umumnya berbentuk bola flattish tidak teratur, diameter $1-10 \mathrm{~cm}$. Kulitnya tipis berwarna coklat muda dengan bagian dalam mengandung tepung berwarna keputihan. Ketika umbi dipotong biasanya akan mengeluarkan ekskresi tipis berwarna keputihan. Jumlah umbi setiap tanaman dewasa dapat mencapai $30 \mathrm{umbi}$, pada umunya berkisar 10 sampai 20 umbi (Spennemann, 1992)

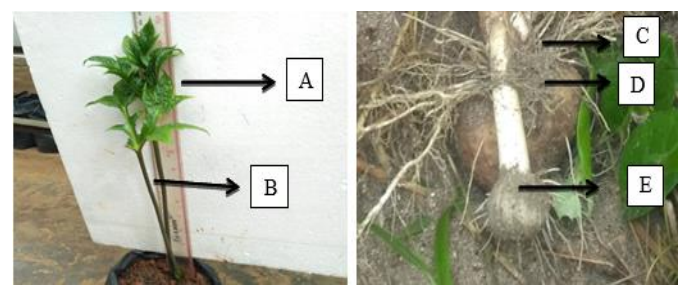

Gambar 1. Tanaman Taka

Keterangan : A. Daun Taka , B. Tangkai Daun Taka, C. Akar Tanaman Taka, D.Umbi Empu Taka, E. Umbi Anakan Taka (Sumber : Dokumentasi Penulis)

Syarif et al. (2014), menyatakan bahwa, pertumbuhan umbi taka akan optimal bila ditanam pada tanah pasir berbahan organik tinggi. Pada tipe tanah tersebut, berat umbi anak taka dapat mencapai lebih dari 1600 gram. Menurut Erlinawati et al (2018), bentuk umbinya taka membulat dan memipih atau menjorong lebar, berkulit tipis, berwarna cokelat tua 
ketika sudah tua. Bagian dalam pada umbi taka berwarna putih susu, tumbuh di bawah permukaan tanah hingga pada kedalaman $50 \mathrm{~cm}$.

Tumbuhan taka cocok pada lingkungan dengan intensitas cahaya 60-80\%. Pada awal pertumbuhannya memerlukan tingkat naungan sekitar $70 \%$, setelah memasuki masa pengisian umbi kebutuhan naungan sekitar $30 \%$. Warna daun taka menguning dan cenderung terbakar yang tumbuh intensitas cahaya penuh (Wawo et al. 2015). Taka akan tumbuh baik pada daerah ternaungi dan tanah berpasir dengan kandungan pasir mencapai 95\%, pH $5,5-6,3$, kandungan $\mathrm{C} / \mathrm{N}$ ratio $12-13$, dan suhu udara $31-34^{\circ} \mathrm{C}$ serta kelembaban udara diatas $60 \%$ (LIPI, 2011). Berdasarkan laporan Meena dan Yadav (2010), taka biasa hidup dibawah tegakan pohon seperti pohon jati ( Tectona grandis L.) dan Terminalia bellirica. Selain itu tanaman ini juga dapat hidup diantara tanaman Curcuma amada Roxb, Dioscorea bulbifera L. serta herba lainnya. Ekowahyuni dan Yenisbar (2018) melaporkan bahwa di Kepulauan Seribu taka tumbuh bersama dengan tanaman Leucaena leucephala, Imperata cylindrica, Echinochloa cruss-gall dan Cyperus rotundus. Laporan Winara dan Murniati, (2018) serta Alhamd, (2018), bahwa taka banyak ditemukan tumbuh berasosiasi dengan jenis vegetasi khas pantai seperti pandan dan ketapang

Tumbuhan ini memiliki potensi besar sebagai sumber pangan alternatif dan sebagai sumber karbohidrat seperti kentang dan jagung yaitu mengandung pati amilosa dan amilopektin (Kuncle et al., 2003). Bahkan menurut Manek et al. (2005) umbi taka mengandung amilosa lebih tinggi dari jagung. Omojola, (2013) menyatakan bahwa kandungan patinya umbi taka setara dengan sejumlah produk pati komersial, seperti singkong, kentang, gandum, dan beras sehingga tepung taka layak digunakan sebagai bahan baku kue. Energi yang terkandung dalam umbi taka mencapai 285,9 K.cal/100 gram umbi (Swarnkar dan Katewa, 2009). Habila et al. (2011) mengemukakan bahwa taka merupakan sumber anti oksidan yang baik. Hasil penelitian Aissatau et al. (2017) bahwa studi histopatologi mengungkapkan bahwa ekstrak tidak memperbaiki kerusakan sel hati dan glomerulus ginjal yang disebabkan oleh Diet Tinggi Lemak. Ekstrak umbi air dari $T$. leontopetaloides menunjukkan aktivitas antihyperlipidemia dan hipolipidemik; karenanya bisa menjadi penting dalam pengelolaan penyakit kardiovaskular pada tikus. Ukpabi et al. (2009) menambahkan bahwa umbi taka mempunyai kandungan vitamin C mencapai 40,1 mg/100 gram. Nilai gizi umbi taka per $100 \mathrm{mg}$ adalah sebagai berikut: karbohidrat $(85.74 \mathrm{~g})$, kalsium $(58.0 \mathrm{mg})$, fosfor, (7.2 mg), dan air (12.1\%), kalori (3.46 kal), dan abu (1.89 g) (Spennemann, 1994; Martin et al., 2012). Umbi taka juga diketahui memiliki kandungan nutrisi yang cukup lengkap nutrisi dan mineral tersebut antara lain kalsium, zat besi, natrium, kalium, dan magnesium (Swarnkar dan Ketewa, 2009).

Penelitian Suhartono dan Winara (2019) yang dilakukan di Kecamatan Cikelet Kabupaten Garut, tujuannya untuk mengetahui kelayakan usahatani taka di bawah tegakan jati hutan rakyat. Hasil penelitiannya menunjukkan bahwa usahatani taka pada jarak tanam $75 \times 75 \mathrm{~cm}$ dengan produksi akhir tepung lebih layak dijalankan dibanding dengan jarak tanam 50 × $50 \mathrm{~cm}$ dan $100 \times 100 \mathrm{~cm}$. Untuk tujuan usaha jangka panjang, usahatani taka berpotensi menjadi agribisnis yang menguntungkan dengan NPV 14.400.059,11 dan Net B/C 1,08.

Tanaman taka sebagai komoditas baru mempunyai beberapa hal yang akan dikembangkan, yaitu diantaranya teknologi pengembangannya yang perlu disiapkan, salah satunya adalah melakukan domestikasi dan teknik budidaya yang cocok sehingga didapatkan umbi yang baik. Penelitian tanaman taka masih sangat sedikit terutama aspek pengembangannya di Indonesia. Beberapa hal yang telah dilakukan, yaitu etnobotani, teknologi kultur jaringan, respon fisiologi terhadap kondisi tertentu, hingga olahan makanan berbahan umbi taka (Martin et al., 2011; Alhamd, 2012; Miftakhusholikhah, 2014; Alhamd, 2018).

Komposisi media tanam pada masa pembibitan sangat penting karena dapat mempengaruhi penyerapan hara dan kondisi drainase pada pertumbuhan tanaman. Menurut Jumin (2010) bahwa keseimbangan unsur hara dalam tanah sangat perlu untuk menjaga kesuburan tanah. Permulaan fase vegetatif akan meningkatkan asimilat yang dipergunakan untuk pembentukan organ-organ baru, diantaranya organ penyimpanan. Proses ini akan membutuhkan unsur hara yang lebih besar yang diserap tanaman dari tanah yang sebagian besar bersumber dari pupuk. Hanafiah (2005) menyatakan bahwa tanah yang berstruktur baik akan mempunyai kondisi drainase dan aerasi yang baik sehingga sistem perakaran tanaman lebih baik untuk masuk kedalam tanah dan mengabsorbsi air dan hara.

Persyaratan media tanam yang baik menurut Purwanto (2006), ada 5 faktor yaitu: (1) mampu mengikat dan menyimpan air serta hara dengan baik, (2) memiliki aerasi dan drainase yang baik, (3) tidak menjadi sumber penyakit, (4)cukup porous (memiliki banyak rongga) sehingga mampu menyimpan oksigen yang diperlukan untuk proses respirasi (pernapasan), dan (5) tahan lama. Hartmann dan Kester (1978), menyatakan bahwa, pasir mengandung unsur hara sangat sedikit dan sangat rendah kapasitas menahan airnya sehingga penggunaannya sebagai media tanam harus dicampur dengan bahan organik. Menurut Fetiandreny (2007), kandungan unsur hara pasir yaitu N, P, K sangat rendah sampai sedang, selain itu daya pegang airnya sangat rendah sehingga menyebabkan pertumbuhan terhambat.

Menurut Haryadi (1989), pupuk kandang sapi (pukan), merupakan massa heterogen dari senyawa organik dalam berbagai keadaan rombakan dan merupakan pupuk tidak seimbang, karena kandungan fosfatnya yang rendah. Pemberian pukan pada tanaman sayuran dalam jumlah sedang (20-30 ton/ha) dikombinasikan dengan pupuk buatan (200-400 kg/ha) hasilnya lebih tinggi daripada 
pemberian pukan saja (50-80 ton/ha). Menurut Hardjowigeno (2010), faktor yang mempengaruhi komposisi kimia pupuk kandang bervariasi tergantung pada jenis dan umur hewan, makanan, amparan, dan sistem pengelolaan pupuk kandang. Hasil penelitian Fetiandreny (2007) menunjukkan bahwa tinggi tanaman, jumlah sulur tanah dapat meningkat dengan penambahan pupuk kandang. Semua komponen pertumbuhan dan produksi vegetatif tanaman karuk juga meningkat dengan penambahan pupuk kandang sapi. Hal tersebut diduga karena cukupnya bahan organik dan unsur hara esensial dalam pupuk kandang sapi. Menurut Andayani dan Sarido (2013) menambahkan bahwa pupuk kandang sapi mengandung mineral antara lain

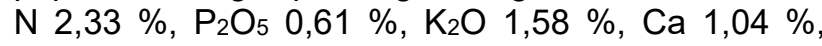
Mg 0,33\%, Mn 179 ppm dan Zn 70,5 ppm.

Tanaman taka agak sulit dibudidayakan karena sifat dorman umbi yang dimilikinya yang menyebabkan tanaman taka tidak selalu tersedia sepanjang waktu, sehingga untuk perbanyakannya diperlukan teknik optimasi media pertumbuhan untuk menyediakan sumber bahan tanaman. Pada penelitian ini akan dipakai media berbagai kombinasi media tanam pasir malang, tanah dan pupuk kandang. Didapatkannya kombinasi media tanam yang terbaik untuk pertumbuhan tanaman taka sehingga bisa dipakai untuk peningkatan pertumbuhan nya

Penelitian ini bertujuan untuk untuk mengetahui komposisi media tanam terbaik pertumbuhan dan perkembangan taka (Tacca leontopetaloides L.Kuntze).

\section{BAHAN DAN METODE}

Penelitian sudah dilakukan pada bulan Desember 2018 sampai dengan Juli 2019, di Kepulauan Seribu dan di Green House Bambu Kuning Fakultas Pertanian Universitas Nasional Jl. Bambu Kuning Pasar Minggu Jakarta Selatan. Bahan yang digunakan adalah umbi taka empu berbatang hitam (variasi batang taka ada hitam dan hijau) dengan bobot 100-300 gram (yang berasal dari kepulauan Seribu), fungisida non sistemik, protektan dengan bahan aktif Mankozeb 80\%, ZPT dengan komposisi (IAA, Sitokinin, ABA, IBA, GA3, Etilen, Asam Traumalin, dan humik acid), pasir malang, tanah, pupuk kandang sapi, pupuk NPK, abu gosok. Rancangan lingkungan yang digunakan adalah Rancangan Acak Kelompok (RAK) in Time. Perlakuan media tanam (M) terdiri dari 3 taraf, yaitu : $\mathrm{M}_{1}=$ pasir malang : tanah $(1: 1 \mathrm{v} / \mathrm{v})$, $\mathrm{M}_{2}=$ pasir malang : tanah : pupuk kandang sapi $(1: 1: 1$ $\mathrm{v} / \mathrm{v}), \mathrm{M}_{3}=$ pasir malang: tanah : pupuk kandang sapi (2:1:1 v/v), dengan 3 kali. Satu satuan percobaan terdiri dari 2 tanaman.

Umbi taka ditanam dalam polibag dengan volume $5 \mathrm{~kg}$ media. Polibag diisi media tanam sesuai dengan perlakuan. Sebelum ditanam umbi dipisahkan dari batangnya, dibersihkan dan ditimbang. Umbi yang sudah ditimbang dilukai pada kedua sisi serta dilumuri fungisida dan abu dapur, kemudian dikering anginkan kurang lebih dua hari. Umbi tadi kemudian direndam dalam ZPT dengan komposisi (IAA, Sitokinin, ABA, IBA, GA3, Etilen, Asam Traumalin, danHumik acid), dengan konsentrasi $4 \mathrm{ml}$ dalam 1 liter air selama \pm 2 jam. Kemudian umbi disemai dalam media yang telah disiapkan sesuai perlakuan. Umbi tanaman taka yang sudah ditanam dalam polibag kemudian ditumbuhkan di Green House, lalu disungkup dengan penutup plastic UV dan tinggi sungkupan $60 \mathrm{~cm}$.

Penyiraman, penyiangan gulma, dan pemupukan, merupakan pemeliharaan tanaman yang perlu dilakukan. Penyiraman merupakan kegiatan yang sangat penting dalam budidaya tanaman taka. Penyiraman dilakukan dua hari sekali pada sore hari. Penyiangan gulma dilakukan setiap bulan dengan bersamaan penggemburan tanah di sekitar tanaman sehingga aerasi lebih baik dan proses pembentukan umbi menjadi lebih baik.

Pemupukan dilakukan setelah tanaman umur 4 minggu pindah tanam dengan pupuk kalium sebanyak 5 gram per tanaman.Pada saat itu, biasanya daun taka masih belum membuka sempurna.Pemupukan kalium kedua dapat dilakukan ketika pemangkasan tangkai perbungaan dengan dosis kalium sebanyak 10 gram per tanaman.Pupuk kalium ditabur mengelilingi batang taka pada kedalaman $5 \mathrm{~cm}$.

Variabel pengamatan yang dilakukan adalah pertumbuhan tunas taka, jumlah daun, tinggi tanaman, lebar daun, dan panjang daun. Data yang diperoleh dianalisis dengan SPSS versi 23 dan uji lanjut menggunakan Duncan Multiple Range Test (DMRT) pada taraf 5\%.

\section{HASIL DAN PEMBAHASAN \\ Kondisi umum}

Kepulau Seribu terletak $45 \mathrm{~km}$ di sebelah Utara Kota Jakarta.Secara geografis Kepulauan Seribu

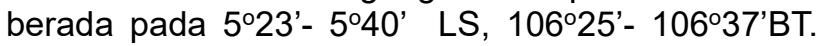
Kepulauan Seribu memiliki 110 pulau yang sudah diverifikasi dan 200 pulau yang masih timbul dan hilang. Pulau-pulau tersebut ada yang berfungsi sebagai pulau pemukiman, pulau konservasi, alam, dan ada yang menjadi pulau resort.

Taka banyak didapatkan di Pulau Pramuka, pulau karya dan pulau Kotok Besar. Tanaman taka dari pulau Karya (Gambar 2).
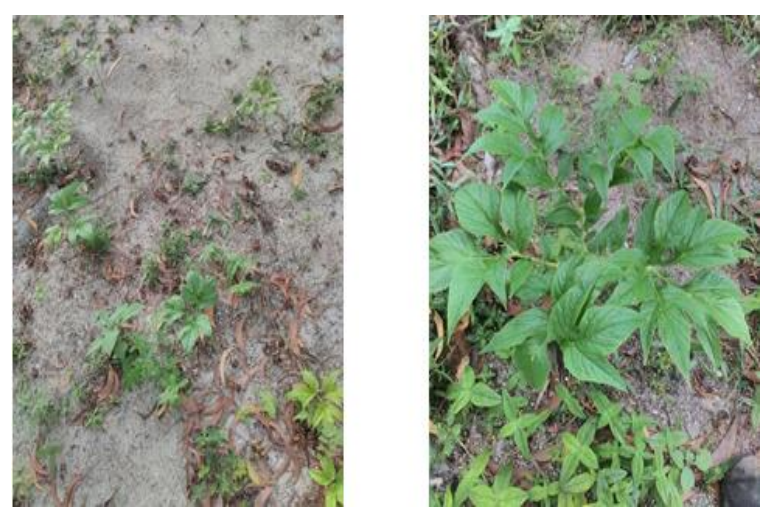

Gambar 2 Taka dari Pulau Karya (Sumber : Dokumentasi Penulis) 
Umbi taka yang dipakai sebagai sumber tanaman yang berasal dari Kepulauan Seribu diambil umbi empu dengan batang hitam (Gambar 3).
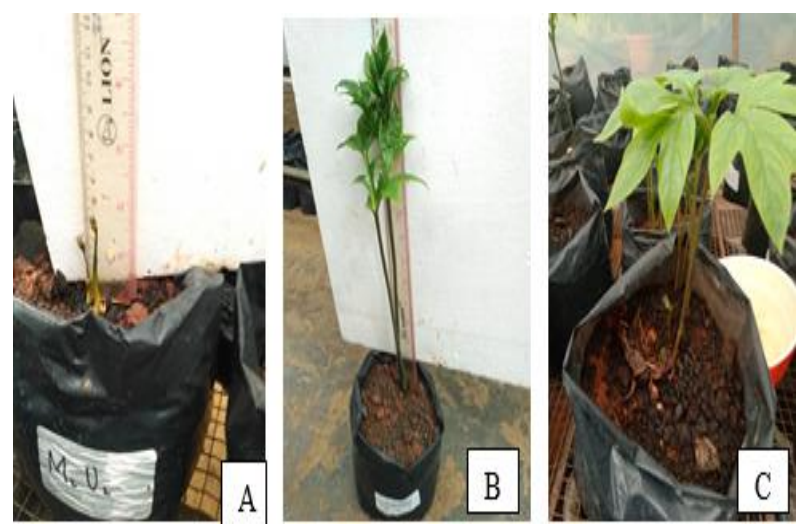

Gambar 3 Tanaman Taka Pada Beberapa Umur

A. Umur 14 MST, B. Umur 18 MST, C. Umur 22 MST (Sumber : Dokumentasi Penulis)

\section{Jumlah daun taka}

Media tanam berpengaruh tidak nyata pada jumlah daun tanaman taka. Media tanam pasir malang yang lebih tinggi dengan penambahan pupukkandang menghasilkan jumlah daun yang lebih banyak pada umur 12-15 minggu.

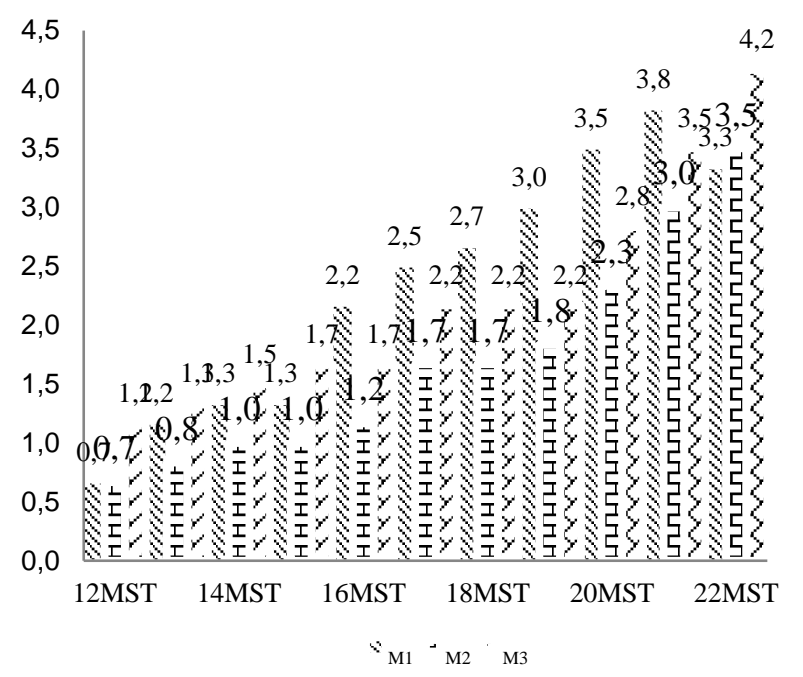

Gambar 4. Jumlah Daun Taka Pada Komposisi Media Umur 12-22 MST

Media pasir malang, tanah yang sebanding menghasilkan jumlah daun taka yang lebih banyak pada umur 16-21 minggu. Jumlah daun taka pada media dengan komposisi pasir malang: tanah (1:1 v/v) lebih banyak (2,4 helai), sedangkan media tanam pasir malang, tanah dan pupuk kandang sapi (2:1:1 v/v) jumlah daunnya (2,2 helai) dan media tanam pasir malang, tanah, dan pupuk kandang sapi (1:1:1 v/v) (1,7 helai) (Gambar 4 dan 5).

Pada satu tanaman terdapat ada 4 atau 2 daun. Hal ini sesuai dengan pendapat Syarif et al. (2014) bahwa, terdapat satu sampai empat tangkai daun, satu sampai dua tangkai perbungaan, satu umbi empu, dan satu sampai beberapa umbi setiap individu tanaman taka. Jumlah daun dipengaruhi oleh faktor genetik dan perlakuan komposisi media.

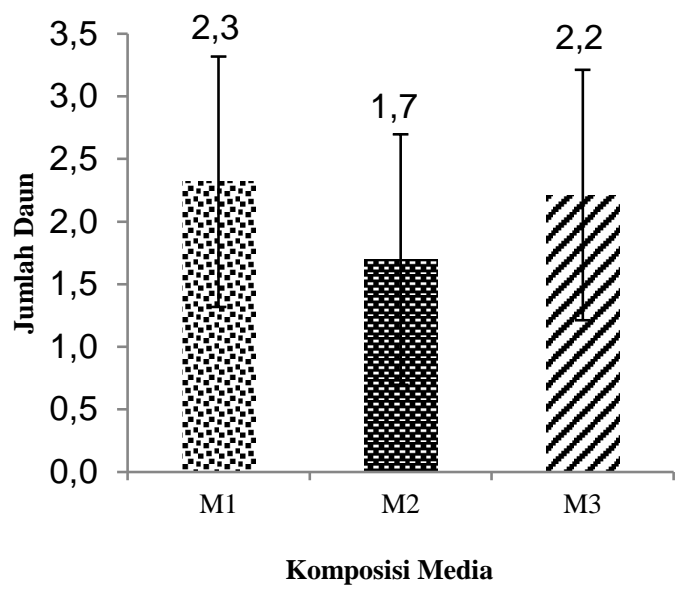

Gambar 5. Jumlah Daun Taka pada Komposisi Media 12-22 MST

\section{Lebar dan panjang daun taka}

Media tanam pada komposisi yang berimbang antara pasir malang, tanah dan pupuk kandang sapi menghasilkan lebar dan panjang (Gambar 6 dan 7).

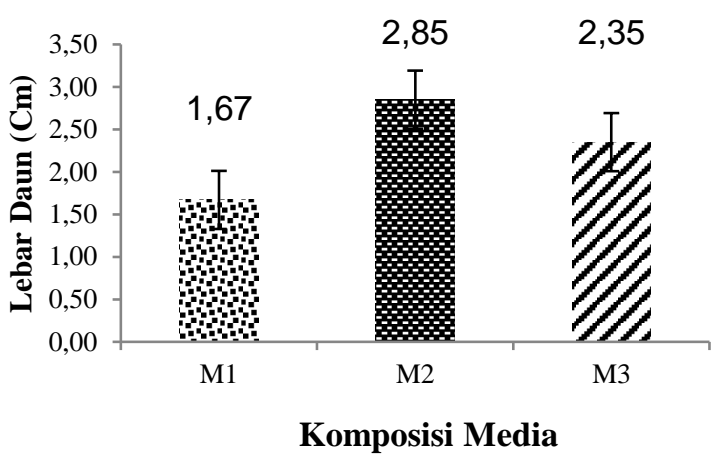

Gambar 6. Lebar Daun Taka Umur 22 MST pada Beberapa Kombinasi Media Tanam

Hal ini menunjukkan bahwa respon dari pupuk kandang sapi memberikan respon yang baik. Hal ini didukung oleh Aisyah (2011) bahwa Proses pertumbuhan ditandai dengan terjadinya peningkatan beberapa bagian tanaman seperti peningkatan tinggi tanaman, panjang daun, lebar daun, dan berat seluruh begian tanaman. Pertumbuhan dan perkembangan tanaman merupakan suatu proses penting dalam perkembangbiakan suatu tanaman.

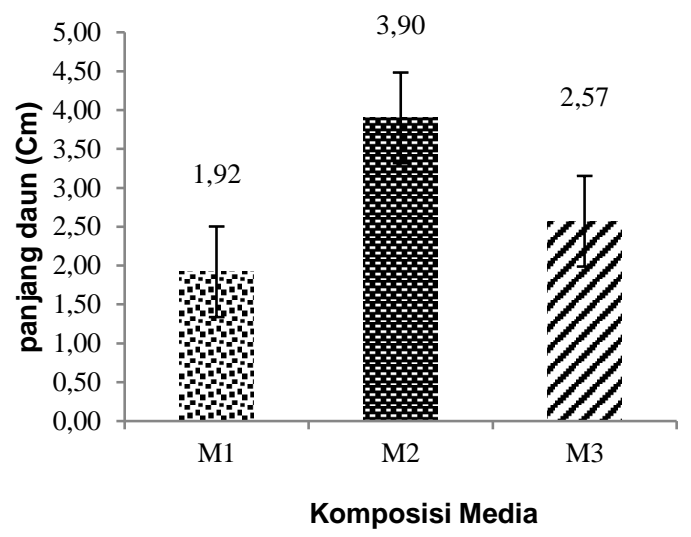

Gambar 7. Panjang Daun Taka Umur 22 MST pada Beberapa Kombinasi Media Tanam 
Ditambahkan oleh Salisbury dan Ross (1995) bahwa sinar matahari yang diserap oleh daun merupakan faktor penentu pada proses fotosintesis. Sehingga menghasilkan lebar dan panjang daun yang lebih tinggi. Hal ini didukung oleh Hanum (2010) yang menyatakan bahwa pertumbuhan vegetatif pada tanaman asparagus berpengaruh baik dengan pemberian media tanam campuran pasir dan kompos.
Tanaman yang menyukai iklim kering seperti Adenium, Euphorbia dan Sanseviera cocok pada media pasir malang sehingga merupakan salah satu media tanam yang banyak digunakan. Menurut Oktoniartiningsih, (2007), bahwa komposisi media yang baik untuk pertumbuhan adenium adalah adalah M1 (pasir malang : arang sekam : pupuk kandang $=1: 1: 1$.

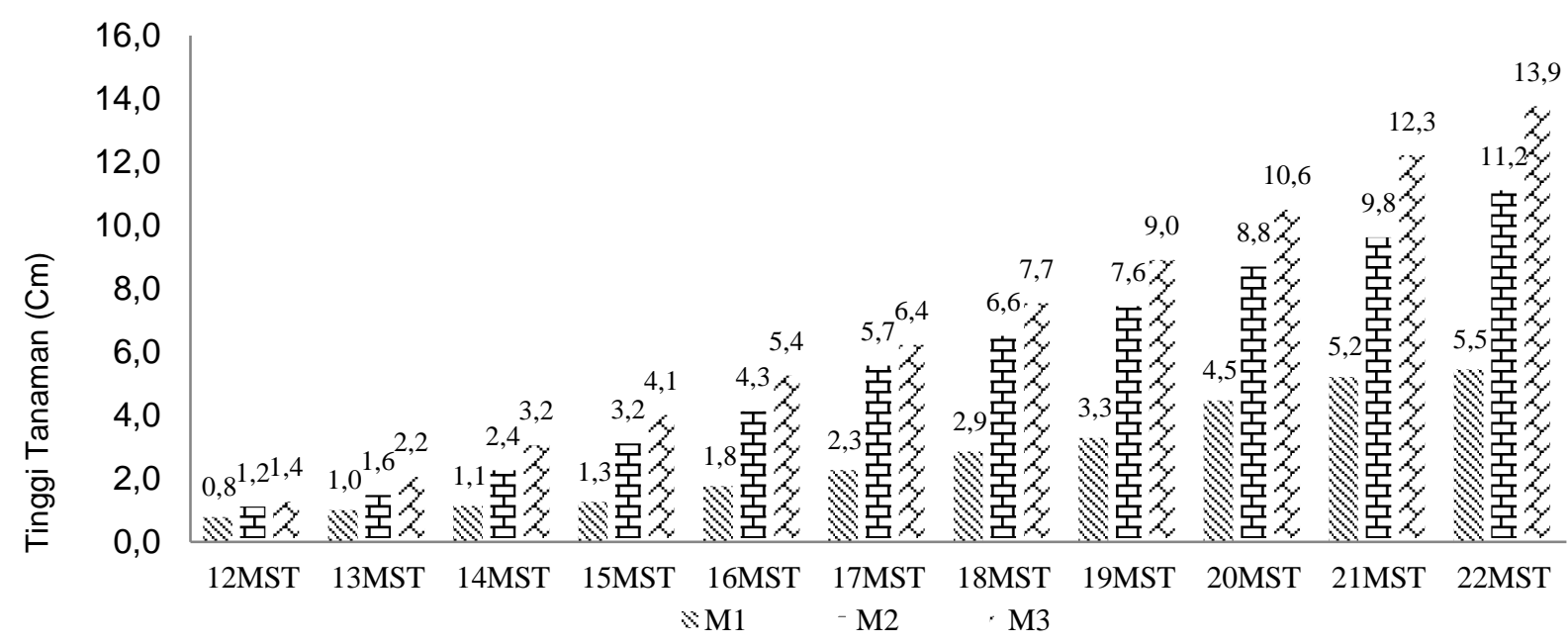

Gambar 8. Tinggi Tanaman Taka pada Beberapa Komposisi Media Tanam

\section{Tinggi tanaman taka}

Media tanam berpengaruh tidak nyata pada tinggi tanaman taka umur 12-22 minggu. Media tanam dengan pasir malang yang lebih banyak dan penambahan pupuk kandang menghasilkan tinggi tanaman yang lebih besar dibandingkan dengan media tanam yang lebih sedikit. (Gambar 8 dan 9).

Mulyani (2002) menyatakan peranan jasad renik yang merubah bahan bahan yang terkandung dalam pupuk menjadi zat-zat hara yang tersedia dalam tanah untuk mencukupi keperluan pertumbuhan tanaman mengalami hambatan, apabila pupuk kandang padat yang banyak mengandung air dan lendir. Hal ini disebabkan pupuk yang demikian bila terpengaruh oleh udara maka akan terjadi pergerakan-pergerakan sehingga keadaannya menjadi keras, selanjutnya air tanah dan udara yang akan melapukkan pupuk itu menjadi sukar merembes kedalamnya. Pertumbuhan tanaman yang baik dapat menjadi harapan bagi hasil yang akan diambil.

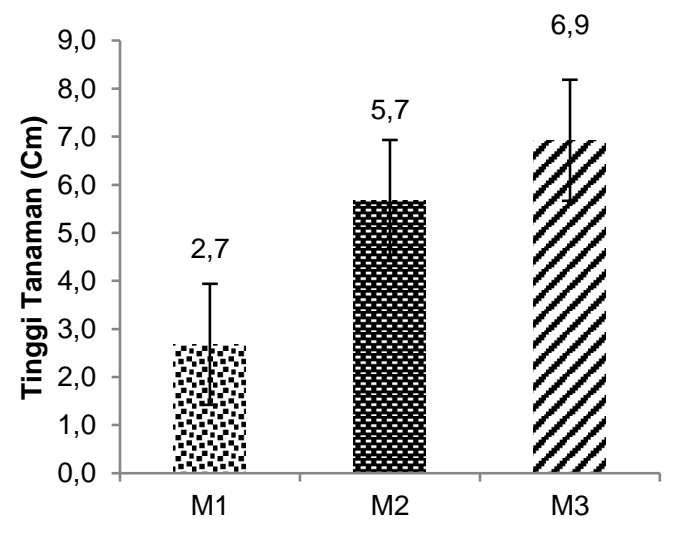

Gambar 9. Tinggi Tanaman Taka pada Beberapa Kombinasi Media Tanam

\section{KESIMPULAN}

Perlakuan media yang paling baik untuk jumlah daun yaitu pasir malang : tanah. Tinggi tanaman tertinggi pada media pasir malang : tanah : pupuk kandang (2:1:1). Lebar dan panjang daun paling tinggi pada media pasir malang : tanah : pupuk kandang $(1: 1: 1)$.

\section{UCAPAN TERIMA KASIH}

Penulis mengucapkan terima kasih kepada Prof. Ernawati Sinaga M.S., Apt. Selaku Warek PPMK Universitas Nasional yang telah memberikan sebagian dana pada penelitian Kompetitif Universitas Nasional No. 161 Tahun 2018. Terima kasih ditujukan kepada Dekan dan Kepala Lab serta Kebun Percobaan Fakultas Pertanian Universitas Nasional. Terima kasih kepada Herman, S.Si yang telah membantu dalam eksplorasi taka sebagai sumber bahan penelitian dan semua pihak yang telah membantu dalam pelaksanaan kegiatan penelitian ini.

\section{DAFTAR PUSTAKA}

Aisyah, S. (2011). Pengaruh Urin Sapi Terfermentasi Dengan Dosis dan Interval Pemberian yang berbeda Terhadap Pertumbuhan Tanaman Sawi (Brassica juncea L). Skripsi. Program Studi Agroteknologi, Fakultas Pertanian dan Peternakan, Universitas Islam Negeri Sultan Syarif Kasim, Riau.

Alhamd, L. (2012a). Biomassa Tumbuhan Taka (Tacca leontopetaloides) di Sekitar Taman Nasional Karimunjawa, Jawa Tengah. In Prosiding Simposium dan Seminar Bersama PERAGI-PEHORTI-PERIPI-HIGI. Bogor (pp. 1-2). 
Alhamd, L. (2018b). Ecological Study of Arrowroot (Tacca leontopetaloides (L.) Kuntze) at Karimunjawa National Park, Central Java. Reinwardtia, 17(2), 87-96.

Andayani, \& Sarido, L. (2013). Uji Empat Jenis Pupuk Kandang Terhadap Petumbuhan Dan Hasil Tanaman Cabai Keriting (Capsicum annum L.). Jurnal AGRIFOR XII (1) : 22-29.

Assatou, D. S., Metsagang, J. T. N., Sokeng, C. D., \& Njintang, N. Y., (2017). Anthyperlipidemic and hypolipidemic properties of Tacca leontipetaloudes L. Kuntze (Dioscoreacea) tubers aqyeous extract in the rats. Brazilian Jurnal of Biological Science, 4(7):67-80.

Ekowahyuni, L. P., \& Yenisbar. (2018). Eksplorasi dan Domestikasi Tanaman Tacca. Fakultas Pertanian, Universitas Nasional, Jakarta.

Elizabeth, R. (2011). Strategi Pencapaian Diversifikasi dan Kemandirian Pangan: Antara Harapan dan Kenyataan. Iptek Tanaman Pangan. 6 (2): 230-242.

Erlinawati, I., Lestari, P., Ermayanti, T. M., \& Rugayah. (2018). Taka (Tacca leontopetaloides) untuk Kemandirian Pangan. ISSN / ISBN / IBSN : ISBN 978-979-799-986-5; e-book 978-979-799-987-2. LIPI Pres. Bogor.

Fetiandreny, M. (2007). Pengaruh Campuran Media Tanam Terhadap Pertumbuhan dan Produksi Karuk (Piper sarmentosum Roxb. Ex Hunter). Skripsi. Fakultas Pertanian, Institut Pertanian Bogor, Bogor.

Habila, J. D., Dzikwe, A. A., Bello, I., \& Ladan, Z. (2011). Comparative Evaluation of Phytochemicals, Anti Oxidant and Anti Microbial Activity of Four Medical Plants Native To Northern Nigeria. Australian Journal of Basic And Applied Science. 5 (5): 537-543.

Hanafiah, K. A. (2005). Dasar-Dasar IImu Tanah. Raja Grafindo, Jakarta.

Hanum, M. (2010). Pengaruh Jenis Media Tanam terhadap Pertumbuhan Bibit Tanaman Asparagus (Asparagus officinalis L.). Skripsi. Departemen Agronomi dan Hortikultura. Fakultas Pertanian. Institut Pertanian Bogor, Bogor. 38 hal.

Hardjowigeno, S. (2010). IImu Tanah. CV Akademika Pressindo, Jakarta.

Heyne, K. (1987). Tumbuhan Berguna Indonesia IV. Balai Penelitian dan Pengembangan Kehutanan, editor. Yayasan Sarana Warna Jaya, Jakarta.

Jumin, H. B. (2010). Dasar Dasar Agronomi. Rajawali Press, Jakarta.

LIPI. (2011). Tumbuhan Liar Sumber Pangan Alternatif Prospektif Nasional dari Kabupaten Garut. (online).

http://www.garutkab.go.id/pub/news/detail/7553jalawure-tumbuhan-liarsumber-panganalternatif.html. Diakses pada tanggal 30 januari 2019.
Manek, R. V., Emeje, M. O., Kunle, O. O., \& Builders, P. (2005). Physical, Thermal, and Sorption Profile of Starch Obtained From Tacca leontopetaloides. Starch - Starke. 57(2): 55-61.

Martin, A. F., Ermayanti, T. M., Wulandari, D. R., Hapsari, B. W., Rantau, D. E., \& Rudiyanto. (2011). Penyediaan Bibit Unggul Tanaman Tacca leontopetaloides Secara In Vitro Untuk Pengembangan Pangan Alternatif. http:// www.Biotek.Lipi.Go.Id/Index.Php/ResearchAdevelopment/156-Riset-2011/853-PenyedianBibitunggul-Tanaman-Tacca-LeontopetaloidesSecara-In-Vitro-Untuk-Pengembangan-PanganAlternatif. Diakses pada tanggal 11 Februari 2019.

Martin, A. F., Ermayanti, T. M., Hapsari, B. W., \& Rantau, D. E. (2012). Rapid Micropropagation of Tacca leontopetaloides (L.) Kuntze. The 5th Indonesia Biotechnology Conference. Hal: $240-251$.

Meena, K. L., \& Yadav, B. L. (2010). Tacca leontopetaloides (Linn) O Kuntze (Taccaceae) New Record to the Flora of Rajhastan. Indian Journal of Nature Products and Recources. 1 (4): 512-514.

Miftakhusholikhah. (2014). Karakteristik Tepung dan Pati Tacca (Tacca leontopetaloides) Serta Aplikasinya Untuk Pembuatan Noodle. Skripsi. Fakultas Pertanian. Universitas Gadjah Mada, Yogyakarta.

Mulyani, S. (2002). Pupuk dan Cara Pemupukan. Rineka Cipta, Jakarta.

Oktoniartiningsih, A. (2007). Pengaruh Komposisi Media dan Dosis Pupuk Dekastar Plus Terhadap Pertumbuhan Adenium (Plumeria acuminate Var. Adenium). Universitas Muhammadiyah Malang, Malang.

Omojola, M. O. (2013). Tacca Starch: A Review of Its Production, Physicochemical Properties, Modification and Industrial Uses. African Journal of Food, Agriculture, Nutrition, And Development. 13(4): 72-79.

Purwanto, A. W. (2006). Aglaonema Pesona Kecantikan Sang Ratu Daun. Kanisius, Yogyakarta.

Salisbury, F. B., \& Ross, C. W. (1995). Fisiologi Tumbuhan (Plant Physiology). Lukman DR, Sumaryono, editor. ITB, Bandung.

Spennemann, D. H. R. (1992a). Notes on The Occurrence, utilisation, and importance of Polynesian Arrowroot (Tacca leontopetaloides) in Marshall Island. Majuro, Marshall Islands: Ministry of Sosial Services, Family Food an Nutrition Project.

Spennemann, D. H. R. (1994b). Traditional Arrowroot Production And Utilization In The Marshall Island. J. Ethnobiol. 14(2): 211-234.

Suhartono, \& Winara. (2019). Kelayakan Usahatani Jalawure (Tacca leontopetaloides). Jurnal of Forestery Research FALOAK 3(2):76-89. 
Susanto, R. (2014). Pengaruh Kombinasi Media Tanam dengan Bobot Umbi Mini terhadap Pertumbuhan Tanaman Tacca (Tacca leontipetaloides (Linn.) O.Kuntze. Skripsi.Fakultas Pertanian. Institut Pertanian Bogor, Bogor.

Swarnkar, S., \& Katewa, S. S. (2009). Nutritional Evaluation of Some Wild Roots and Tubers From Area of Rajasthan, India. J. Root Crops. 35(1): 86-91.

Syarif, F., Lestari, P. \& Wawo, A. H. (2014). Variasi Karakteristik Pertumbuhan Tacca Leontopetaloides (L) Kuntze (Taccaceae) di Pulau Jawa dan Pulau-Pulau Kecil Sekitarnya. Berita Biologi 13(2):161-171.
Ukpabi, U. J., Ukenye, E., \& Olojede, A. O. (2009). Raw-material Potentials of Nigerian Polynesian Arrowroot (Tacca Leontopetaloides) Tuber and Starch. Journal of Food Technology. 7(4): 135-138.

Wawo, A. H., Lestari, P., \& Utami, N. W. (2015). Studi Perbanyakan Vegetatif Tanaman Taka (Tacca leontopetaloides (L.) Kuntze) dan Pola Pertumbuhannya. Jurnal Berita Biologi. 14 (1): 1-9.

Winara, A., \& Murniati. (2018). Pola Sebaran, Kelimpahan Populasi dan Karakteristik Habitat Jalawure (Tacca leontopetaloides) di Kabupaten Garut. Jurnal Penelitian Hutan dan Konservasi Alam. 15 (2) : 79-89. 